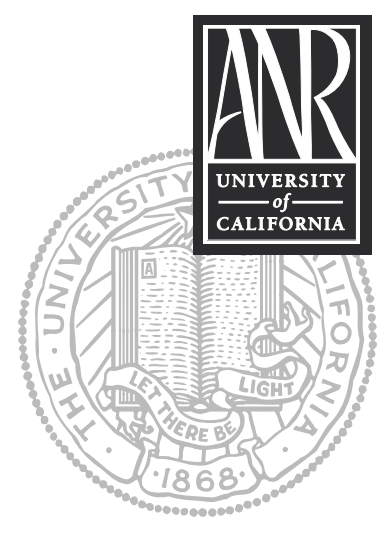

UNIVERSITY OF CALIFORNIA

Division of Agriculture and Natural Resources http://anrcatalog.ucdavis.edu

\title{
Oxidation-Reduction Potential (ORP) for Water Disinfection Monitoring, Control, and Documentation
}

TREVOR V. SUSLOW, Extension Research Specialist, Department of Vegetable Crops, University of California, Davis

Large volumes of water are commonly used during the postharvest handling and processing of minimally processed fruits and vegetables. Economic considerations and wastewater discharge regulations make water recirculation a common practice in the industry. Few practices have the capacity of water recirculation to increase the potential risk of foodborne illness by readily distributing a point source contaminant (one lot, one bin, or even one plant) to noncontaminated produce.

Disinfection of water is a critical step in minimizing the potential transmission of pathogens from a water source to produce, among produce within a lot, and between lots over time. Waterborne microorganisms, whether postharvest plant pathogens or agents of human illness, can be rapidly acquired and taken up on plant surfaces. Natural plant surface contours, openings, harvest and trimming wounds, and handling injuries can serve as points of entry for microbes. Microbes within these protected sites are unaffected by common postharvest water treatments such as chlorine, chlorine dioxide, ozone, peroxide, peroxyacetic acid, UV irradiation, and other approved treatments at legal rates of application. It is essential, therefore, that the water used for washing, cooling, transporting, postharvest drenching, or other procedures be maintained in a condition suitable for the application of these disinfectants. The criteria for the microbial quality of the water become more stringent as product moves from the field to final processing.

Accurate monitoring and recording of disinfection procedures is an important component of a sound postharvest quality and safety program during product cooling and processing. Many packers of raw produce, as well as many processors of fresh cut products, now use sensors to determine the oxidation-reduction potential (ORP) status of their water systems. ORP, measured in millivolts $(\mathrm{mV})$ has increasingly become a primary approach to standardizing water disinfection parameters. Rather than exclusively monitoring dose (for instance, in parts per million, or ppm), postharvest handlers now monitor activity, since ORP reflects the antimicrobial potential of the water, irrespective of the water quality.

Oxidation-reduction potential is the potential (voltage) at which oxidation occurs at the anode (positive) and reduction occurs at the cathode (negative) of an electrochemical cell. In simple terms, from a microbial perspective, an oxidizing chemical pulls electrons away from the cell membrane, causing it to become destabilized and leaky. Destroying the integrity of the cell membrane leads to rapid death. Operationally much like a digital thermometer or $\mathrm{pH}$ probe, ORP sensors allow easy monitoring and tracking of critical disinfectant levels in water systems. Coupled with $\mathrm{pH}$ sensors, more-sophisticated systems use ORP sensors to provide automated "demand-based" injection of hypochlorite (or other approved oxidizing disinfectant) and acid, typically food-grade citric acid, muriatic acid, or phosphoric acid.

CAUTION: Recent evidence from USDA/ARS strongly suggests that citric acid may interfere with the lethal action of hypochlorous acid at levels likely to result in ORP less than or equal to 650-700 mV. Consider using inorganic food-grade acids (e.g., muriatic or phosphoric) instead of citric acid, especially when lower doses (10-25 ppm total chlorine) are being used. 
This publication provides a brief overview of the application of ORP monitoring to postharvest sanitation processes and describes the relationship of $\mathrm{mV}$ values to traditional standards that rely on estimates of parts per million of active disinfectant.

\section{BENEFITS OF ORP SYSTEMS}

Oxidation-reduction potential offers many advantages to "real-time" monitoring and recording of water disinfection potential, a critical water quality parameter. Improvements in probe design and continuous digital recording via computer-linked data input are available. Record keeping can become a largely automated activity. Evaluating process control by water quality, product, and season, for example, is easier with the graphic outputs of available systems. Probes have been integrated with audible, visual, and remote alarm systems (such as pager alerts) to notify the operator of out-of-range operation. Hand-held devices are affordable and are an essential backup for cross-referencing the operation of an inline ORP sensor, as are the more traditional dose-related test kits.

A primary advantage of using ORP for water system monitoring is that it provides the operator with a rapid and single-value assessment of the disinfection potential of water in a postharvest system. The operator is able to assess the activity of the applied disinfectant rather than the applied dose. Research has shown that at an ORP value of 650 to $700 \mathrm{mV}$, free-floating decay and spoilage bacteria as well as pathogenic bacteria such as E. coli O157:H7 or Salmonella species are killed within 30 seconds (see table 1). Spoilage yeast and the more-sensitive types of spore-forming fungi are also killed at this level after a contact time of a few minutes or less.

Table 1. Summary of results from various lab simulation and commercial hydrocooler survey studies

\begin{tabular}{|l|c|c|c|}
\hline & \multicolumn{3}{|c|}{ Survival in seconds $(\mathrm{s})$ or hours $(\mathrm{h})$ at $\mathrm{ORP}(\mathrm{mV})$} \\
\hline Pathogen/Indicator & $<485$ & $550<\times<620$ & $>665$ \\
\hline E. coli 0157:H7 & $>300 \mathrm{~s}$ & $<60 \mathrm{~s}$ & $<10 \mathrm{~s}$ \\
\hline Salmonella spp. & $>300 \mathrm{~s}$ & $>300 \mathrm{~s}$ & $<20 \mathrm{~s}$ \\
\hline Listeria monocytogenes & $>300 \mathrm{~s}$ & $>300 \mathrm{~s}$ & $<30 \mathrm{~s}$ \\
\hline thermotolerant coliform & $>48 \mathrm{~h}$ & $>48 \mathrm{~h}$ & $<30 \mathrm{~s}$ \\
\hline
\end{tabular}

Unfortunately, resistant spore-forming decay pathogens and human parasites such as Cryptosporidium species are highly tolerant of chlorine, bromine, iodine, and other weak oxidizers or metabolic poisons used for water disinfection. If hazard analysis identifies the potential for the presence of these parasites, treating source water with peroxyacetic acid, ozonation, or high-intensity UV light would be a suitable control measure.

A practical benefit of measuring ORP in postharvest uses such as transport flumes, bindrenchers, cooling flumes, hydrocoolers, water-spray vacuum cooling, ice production, and ice injection is that ORP values accurately define the antimicrobial potential of the water for free-floating microbes. Conventional systems of measuring parts per million using titration kits or paper test strips can give the same information, but it must be combined with a measurement of water $\mathrm{pH}$ and correlated with a table of hypochlorous acid ( $\mathrm{HOCl}$ ) availability (See ANR Publication 7256, Water Disinfection: A Practical Approach to Calculating Dose Values for Preharvest and Postharvest Applications). The water $\mathrm{pH}$ becomes an essential variable since color-based test kits and paper strips detect hypochlorous acid $(\mathrm{HOCl})$ and hypochlorite ions $\left(\mathrm{OCl}^{-}\right)$equally. At $\mathrm{pH} 7.5, \mathrm{HOCl}$ and $\mathrm{OCl}^{-}$are at equilibrium in water (50:50). Lowering the $\mathrm{pH}$ raises the percentage of $\mathrm{HOCl}$, and ORP increases (larger $\mathrm{mV}$ readings) to reflect this shift in oxidative potential. Recent research in commercial and model postharvest water systems has shown that, if necessary, ORP criteria can be relied on to determine microbial kill potential across a broad range of water quality. In other words, an ORP of $700 \mathrm{mV}$ at $\mathrm{pH} 6.5$ has the same "killing" potential as an ORP value of $700 \mathrm{mV}$ at $\mathrm{pH}$ 8.5. It would require a much higher dose of hypochlorite to achieve this constant ORP at $\mathrm{pH} 8.5$, since $\mathrm{HOCl}$ would represent only 15 percent of the total free chlorine. Measurements of the parts per million of free chlorine at these two $\mathrm{pH}$ values (with a constant concentration of hypochlorite) will 
be essentially identical, giving a false sense of adequate water disinfection at $\mathrm{pH} 8.5$ to prevent decay or cross-contamination by human pathogens.

\section{PRACTICAL ORP MEASUREMENT}

ORP measurement should be used as a "window" of operation rather than a fixed point. Sensors rarely establish a fixed point in a real system. The "bounce" observed in the sensor readout may be as much as $25 \mathrm{mV}$, especially in hand-held units, depending on whether the probe is stationary or in motion. The size of the sensing surface also influences the fluctuations in readings: better sensors have a larger detection area. The best approach is to standardize a uniform method for taking measurements and set thresholds for a window of operation that achieves the microbial reduction objectives appropriate for the operation. For hand-held units, we recommend immersing the sensor in a flowing water source for 30 seconds. If the postharvest water is highly turbulent, use a clean plastic container (ideally rinsed twice in distilled water after cleaning) to measure the ORP of a collected sample. Fill the container, swirl, dump the contents, fill again, and immerse the ORP sensor in the water. Gently stir the water with the sensor for 30 seconds, then take the reading for 30 seconds. Although longer periods for measurement may give more-accurate readings, we recommend 30 seconds as the practical limit of operators' patience. We have conducted several independent tests of sequential 30-second monitoring of chlorinated water, and all makes and models of hand-held ORP sensors tested were consistent within their "window" of accuracy.

Monitor the buildup of inorganic and organic solutes and particles (turbidity, total suspended solids, and conductivity) to prevent the excessive application of chlorine or other disinfectants in an effort to maintain a constant ORP set point without periodic complete fresh water turnover. This makes sense from the perspective of cost, sensory quality, safety, and environmental responsibility. Most important, excessive chlorination is more likely to result in the accumulation of a family of trihalomethanes, undesirable disinfection by-products. If trihalomethanes are present at elevated levels, the packer or processor may be subjected to costly wastewater discharge penalties.

\section{DISADVANTAGES OF ORP SYSTEMS}

The potential disadvantages of ORP-based systems are largely operational issues related to equipment maintenance, calibration, and cross-checking of fixed-position sensors. Always have a back-up system of calibrated hand-held ORP probes and standard ppm kits when using ORP-based systems. Sensors become fouled and need periodic cleaning and calibration, and ORP probes may become temporarily saturated by over-injection of disinfectant. It can take several minutes or longer for a sensor to come back to equilibrium with the surrounding water, which can limit the response time.

An additional limitation, as with any dose-monitoring test method, is that ORP relationships are not uniform for all oxidizing disinfectants. Our research has shown that ORP is not a practical method for monitoring the antimicrobial potential of water treated with hydrogen peroxide or peroxyacetic acid. A combination of ORP and chemical indicator monitoring for ozone concentration is necessary to ensure proper water disinfection.

\section{ORP AND OZONE}

In a clean-water system, using ORP to measure the status of dissolved ozone works well. In our experience, however, the strong oxidizing power of ozone in complex (even moderate-turbidity) systems can result in ORP values far below expected values and even negative (reducing) values. In general, monitoring ozone with ORP at the generator source injection site works well but measuring wash water becomes unreli- 
able. Ozone detection kits work well at the limit of approved concentrations for produce cooling and washing operations.

\section{ORP, pH, AND PPM}

The routine measurement of ORP in millivolts is not a linear relation at rates typically used in the produce industry. In general, a ten-fold increase in total or free chlorine concentrations does not result in a corresponding proportional increase in ORP millivolts. This is predominantly a familiarity and comfort issue rather than one that impacts safety standards. For clean water, 3 to $5 \mathrm{ppm}$ free chlorine provides more than adequate microbial control for free-floating bacteria in a very short contact time. This water quality likely results in measurements of $650-700 \mathrm{mV}$ ORP if the water $\mathrm{pH}$ is 6.5 to 7 . Lowering the $\mathrm{pH}$ to 6.0 raises the ORP, as more hypochlorous acid $(\mathrm{HOCl})$ becomes available. Raising the $\mathrm{pH}$ to 8.0 lowers the ORP value, as more hypochlorite ions $\left(\mathrm{OCl}^{-}\right)$are present. Maintaining constant $\mathrm{pH}$ but adding more chlorine raises the ORP to a plateau of 900 to $950 \mathrm{mV}$, generally around $25 \mathrm{ppm} \mathrm{HOCl}$. Doubling the free chlorine does not result in a sizeable gain in ORP and may result in undesirable disinfection by-products, product damage, and flavor tainting. Excessive chlorination, especially at $\mathrm{pH}$ below 6.8 , often creates an uncomfortable and potentially unhealthy environment for workers. For most postharvest systems, it is unnecessary to operate above $800 \mathrm{mV}$, a set point used in primary wash and cooling systems where high concentrations of inorganic and organic matter or harvest and processing wound exudates are released to the water.

\section{FOR FURTHER INFORMATION}

You'll find more information on process water disinfection in the following ANR Communication Services publications:

Ozone Applications for Postharvest Disinfection of Edible Horticultural Crops, Publication 8133, 2004, available for free downloading at http://anrcatalog.ucdavis.edu/pdf/8133.pdf.

Postharvest Chlorination Basics, Publication 8003, 1997, available for free downloading at http://anrcatalog.ucdavis.edu/pdf/8003.pdf.

Postharvest Technology of Horticultural Crops, Second Edition, Publication 3311, 2002.

Water Disinfection: A Practical Approach to Calculating Dose Values for Preharvest and Postharvest Applications, Publication 7256, 2001, available for free downloading at http://anrcatalog.ucdavis.edu/pdf/7256.pdf.

To order or obtain printed publications and other products, visit the ANR Communication Services online catalog at http://anrcatalog.ucdavis.edu. You can also place orders by mail, phone, or FAX, or request a printed catalog of our products from:

University of California

Agriculture and Natural Resources

Communication Services

6701 San Pablo Avenue, 2nd Floor

Oakland, California 94608-1239

Telephone: (800) 994-8849 or (510) 642-2431; FAX: (510) 643-5470

E-mail inquiries: danrcs@ucdavis.edu

An electronic version of this publication is available on the ANR Communication Services Web site at http://anrcatalog.ucdavis.edu.

Publication 8149 
Research support from the California Asparagus Commission, California Lettuce Research Board, California Melon Research Board, California Tree Fruit Agreement, and California Tomato Commission and industry collaborators that contributed to the development of baseline information summarized in this leaflet is gratefully acknowledged. Partial support for the production and distribution of this brochure is contributed by the National Good Agricultural Practices Training Program (USDA CSREES Agreement \# 99-41560-0821)

The information contained in this publication should not be viewed as an authoritative source for current registration status or legal use recommendations of any product. For more information, contact the California Department of Pesticide Registration Information Center at (916) 324-0399.

(C) 2004 by the Regents of the University of California, Division of Agriculture and Natural Resources. All rights reserved.

The University of California prohibits discrimination or harassment of any person on the basis of race, color, national origin, religion, sex, gender identity, pregnancy (including childbirth, and medical conditions related to pregnancy or childbirth), physical or mental disability, medical condition (cancer-related or genetic characteristics), ancestry, marital status, age, sexual orientation, citizenship, or status as a covered veteran (covered veterans are special disabled veterans, recently separated veterans, Vietnam era veterans, or any other veterans who served on active duty during a war or in a campaign or expedition for which a campaign badge has been authorized) in any of its programs or activities. University policy is intended to be consistent with the provisions of applicable State and Federal laws.

Inquiries regarding the University's nondiscrimination policies may be directed to the Affirmative Action/Staff Personnel Services Director, University of California, Agriculture and Natural Resources, 300 Lakeside Drive, 6th Floor, Oakland, CA 94612-3550 (510) 987-0096. For a free catalog of other publications, call (800) 994-8849. For help downloading this publication, call (530) 754-5112.

pr-9/04-SB/CR

ISBN 978-1-60107-319-8

This publication has been anonymously peer reviewed for technical accuracy by University of California scientists and other qualified professionals. This review process was managed by the ANR Associate Editor for Vegetable Crops. 